\title{
Comparative morphology of Cymothoa spp.(Isopoda, Cymothoidae) from Brazilian fishes, with the description of Cymothoa catarinensis sp. nov. and redescriptions of $C$. excisa Perty and $C$. oestrum (Linnaeus) ${ }^{1}$
}

\author{
Vernon E. Thatcher ${ }^{2}$, Jayme de Loyola e Silva ${ }^{2}$, Glauco F. Jost ${ }^{3}$ \& José M. Souza-Conceição ${ }^{3}$ \\ ${ }^{1}$ Contribution number 1444 of the Departamento de Zoologia, Universidade Federal do Paraná. \\ 2 Departamento de Zoologia, Universidade Federal do Paraná. Caixa Postal 19020, 81531-980 Curitiba, Paraná, Brasil. \\ Research Fellows of the CNPq. \\ ${ }^{3}$ Centro de Ciências Tecnológicas da Terra e do Mar (CTTMar), Universidade do Vale do Itajaí. 88302-202 Itajai, Santa \\ Catarina, Brasil.
}

\begin{abstract}
Cymothoa catarinensis sp. nov. collected at Camboriú, Santa Catarina State, Brazil is described. The new species is of small size, has a cephalon that is little immersed in pereonite 1 , anterolateral angles of pereonite 1 that reach or surpass the eyes and a pleon that is deeply immersed in pereonite 7 . The pleopods of the new species have small, lobular accessory gills projecting from the bases. Cymothoa excisa Perty, 1830, and Cymothoa oestrum (Linnaeus, 1758) are redescribed. Both are of large size $(25-35 \mathrm{~mm}$ in length). C. excisa has pointed anterolateral margins of pereonite 1 that reach or surpass the eyes. This species also has trilaminate pleopods in the female and bilaminate pleopods in the male. $C$. oestrum has rounded anterolateral margins of pereonite 1 and no visible eyes. This is the first time the latter species has been reported from Brazil. These three species are compared to four others that have been reported from Brazilian waters, namely: $C$. liannae Sartor \& Pires, 1988; $C$. brasiliensis, $C$. gerris and $C$. ianuarii, all described by Schiödte 8 Meinert, 1884. A key is provided to aid in the separation of the Brazilian species of Cymothoa.
\end{abstract}

KEY WORDS. Atlantic Ocean, Brazil, fish parasites, marine isopods.

Species of the genus Cymothoa Fabricius, 1793, are widely distributed, but they are found only in marine fishes. Only a few studies concerning this genus in South America have been published. The first account of species belonging to this genus found on the Brazilian coast is that of SCHIÖDTE \& MEINERT (1884). SARTOR (1986) published a report concerning the distribution of fishes and cymothoids along the Brazilian coast. Later, SARTOR \& PIRES (1988) described a new species from Southern Brazil. Thatcher (2000) reported four species of Cymothoa from South America. According to Trilles (1991), 32 named species of Cymothoa occur world-wide and five of these are from Brazilian waters. These are: C. brasiliensis Schiödte \& Meinert, 1884; C. excisa Perty, 1830; C. gerris Schiödte \& Meinert, 1884; C. ianuarii Schiödte \& Meinert, 1884 and C. liannae Sartor \& Pires, 1988. Additionally, C. oestrum (Linnaeus, 1793) has been reported from Venezuela and Africa and is reported here for the first time in Brazil. The three species described in 1884 have not been collected since but TriLles $(1979,1981)$ reported finding five specimens in a museum in Holland. The species $C$. excisa and C. oestrum have been reported occasionally but have never been adequately described. For that reason, redescriptions of these species are presented herein. Also, a new species of Cymothoa is proposed and described. The morphology of these species is compared and a key for their separation is presented.

\section{MATERIAL AND METHODS}

Marine fishes were netted on the coasts of Paraná and Santa Catarina States, Brazil. The Cymothoidae Leach, 1818 were removed from the mouths of their hosts and preserved in $70 \%$ ethanol. Appendages were removed with the aid of dissecting needles and cleared in either glycerine or pure phenol for study in temporary preparations. Photographs were taken with a digital camera at five megapixels and drawings were made with the aid of a camera lucida. Measurements are in micrometers $(\mu \mathrm{m})$ unless designated as millimeters $(\mathrm{mm})$.

\section{Cymothoa Fabricius, 1793}

Generic diagnosis: Body symmetrical. Anterolateral corners of pereonite 1 produced to embrace cephalon. Bases of antennae not expanded, well separated. Pereonites 5-6 usually wider than others. Coxal plates small. Pleon narrower than and immersed in pereonite 7. High carinae on bases of pereopods 4-7 and low ones on 1-3. Parasites of the mouths of fishes. 

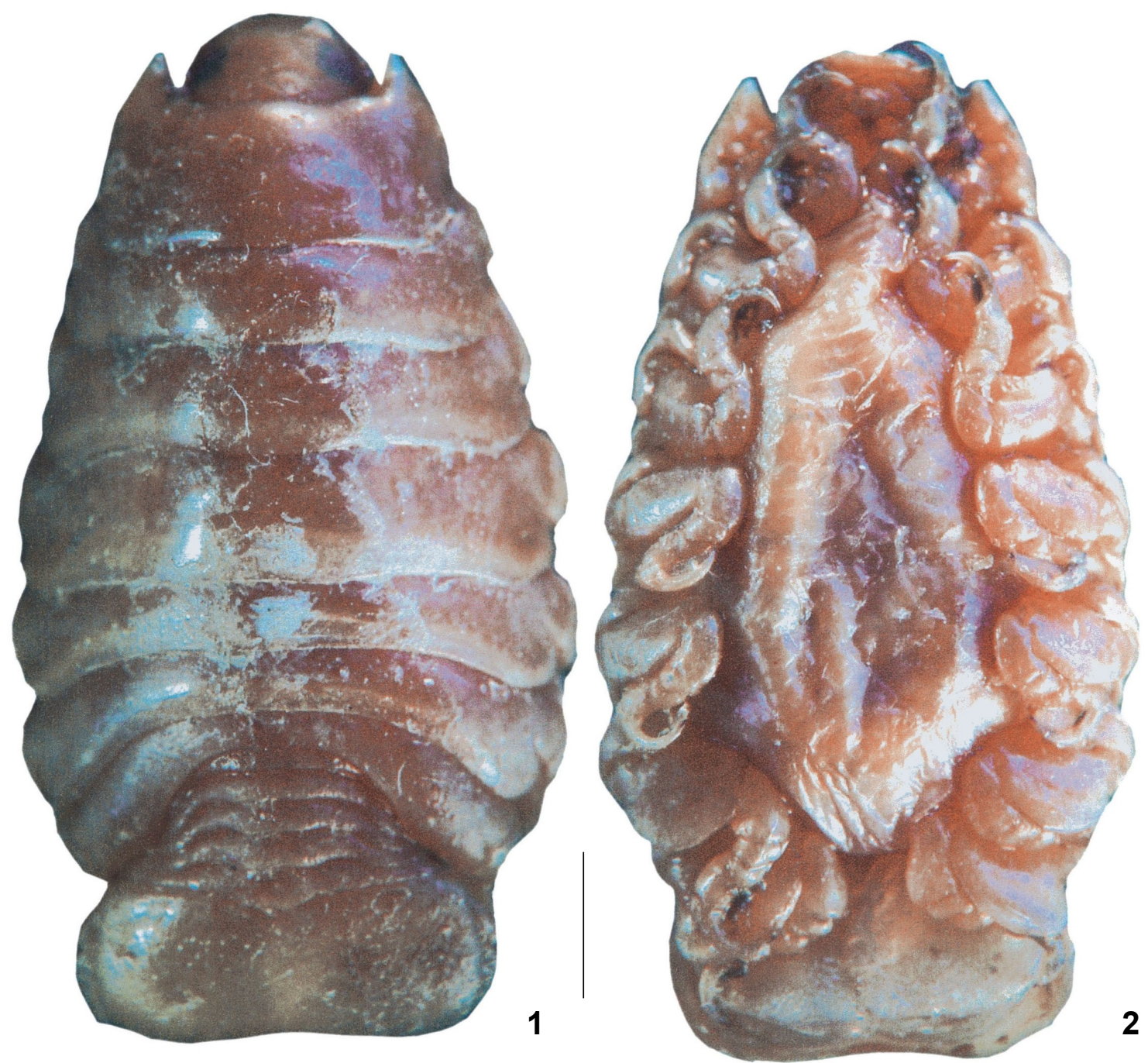

Figures 1-2. Cymothoa catarinensis sp. nov. female: (1) dorsal view; (2) ventral view. Scale $=2000 \mu \mathrm{m}$.

\section{Cymothoa catarinensis sp. nov. \\ Figs $1-26$}

Host: Menticirrhus litoralis (Holbrook, 1860).

Site: Mouth, over tongue.

Localities: Florianópolis, Camboriú and Piçarras, Santa Catarina State, Brazil. Colector: Glauco Fernando Jost: April to December 2000

Intensity: 1-2/fish.

Prevalence: $20 \%$.

Type material: Holotype female and 10 Paratype females deposited in the Crustacean Collection of the Instituto Nacional de Pesquisas da Amazônia (INPA), Manaus, AM, Brazil.

Etymology: The species name is in reference to the Brazilian State in which the species was first collected.
Species description (based on studies of 16 females and 8 males; measurements in table I): Female (Figs 1-2): body small convex dorsally; widest at level of pereonite 5 . Cephalon moderately immersed in pleonite 1 ; frons rounded; eyes present. Antennule (Fig. 5) shorter and stouter than antenna consisting of 8 articles; antenna (Fig. 6) slender, of 8 articles. Mouthparts (Figs 7-9 and 11): Mandible with acute, chitinous incisor and rounded molar process; palp tapered, of three articles, the first being longer and wider than the second and the third being about a third as long as the first; maxillule with four terminal recurved spines; maxilla terminally bilobed with one stout spine on inner lobe and three on outer lobe; maxilliped with numerous setae on distal margin, palp of two articles, situated on midline, with three terminal spines. Pereon: pereonite 1 longest, with acute anterolateral angles that extend midway on eyes; pereonite 4 longer than 2 and 3 , which 

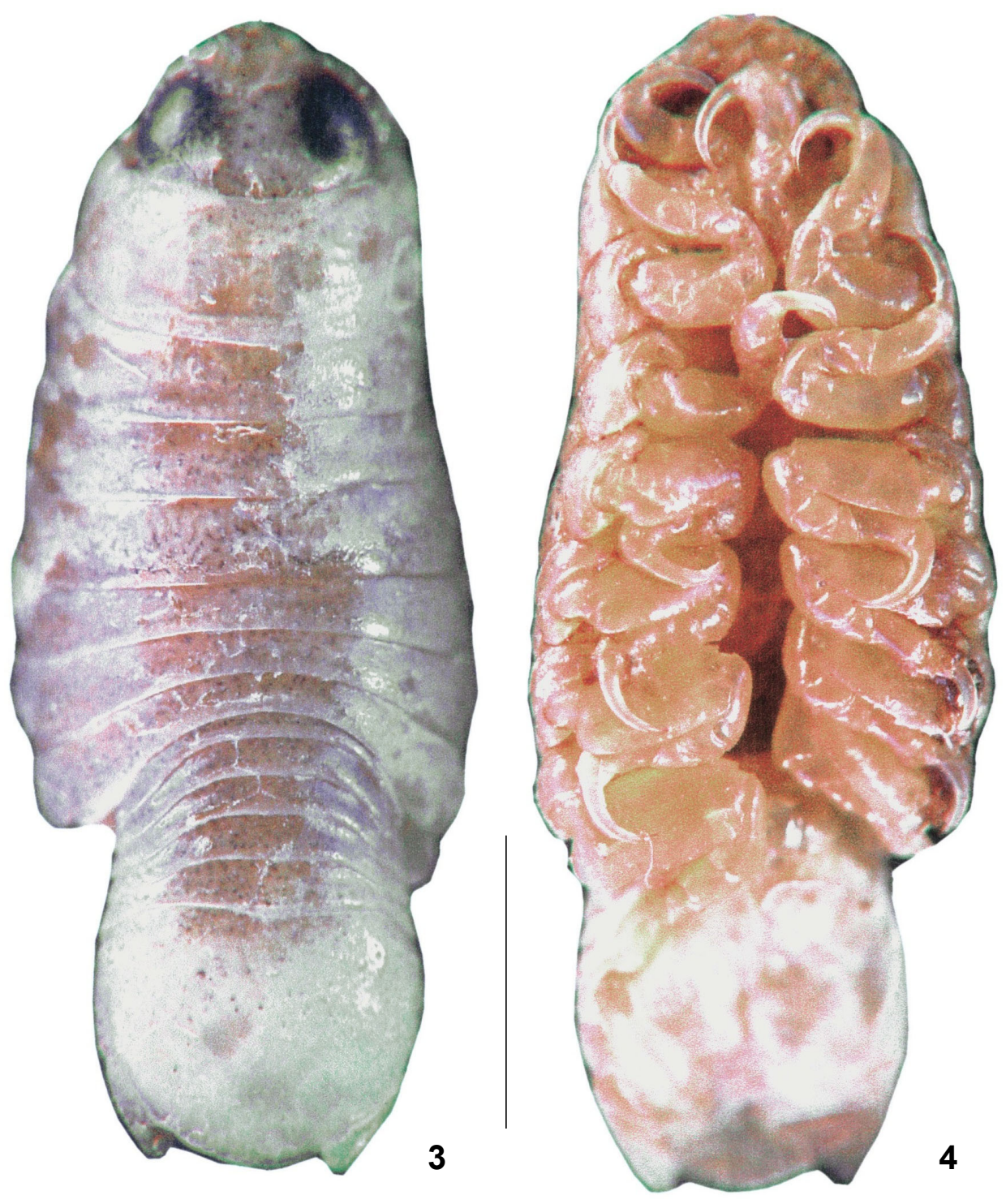

Figures 3-4. Cymothoa catarinensis sp. nov. male: (3) dorsal view; (4) ventral view. Scale $=2000 \mu \mathrm{m}$.

are subequal in length; pereonites 5-7 decrease in length; pereonite 7 reaches to or near pleotelson laterally. Pereopods (Figs 12-18) short, with low carinae on 1-3 and high carinae on 4-7. Pleon deeply immersed in pereonite 7; pleotelson two to three times wider than long. Pleopods (Figs 21-25) bilaminate, rounded, with small accessory gill extending from bases of 2-5. Uropod (Fig. 19) with short, slender rami, exopod only slightly longer than endopod, both provided with few setae; not reaching posterior margin of pleotelson.

Male (Figs 3-4): Body smaller, more slender and less convex dorsally than female. Cephalon not immersed in pereonite 1; frons rounded; eyes large. Maxilliped (Fig. 10) narrower than that of female; palp of 3 articles, with 4 stout recurved spines on terminal article. Pleopod 2 (Fig. 26) with slender appendix masculinum on endopod. Uropod (Fig. 20) similar to that of female but reaches or surpasses posterior margin of pleotelson. Penis not observed.

Manca ( = Pullus II): More than 160 fully formed mancas (Figs 54,55 ) were found in the marsupium of a single female. Body about $2600 \mu \mathrm{m}$ long and $1000 \mu \mathrm{m}$ wide. Cephalon truncate, $485 \mu \mathrm{m}$ long and $675 \mu \mathrm{m}$ wide; eyes large, ovoid, black; antennae longer than antennules, reach to middle of pereonite 1 ; both of 8 articles. Uropods extending well beyond posterior margin of pleotelson; endopod shorter than exopod.

Discussion. Distinguishing characters of the female of Cymothoa catarinensis sp. nov. are its small size, free cephalon,

Revista Brasileira de Zoologia 20 (3): 541-552, setembro 2003 

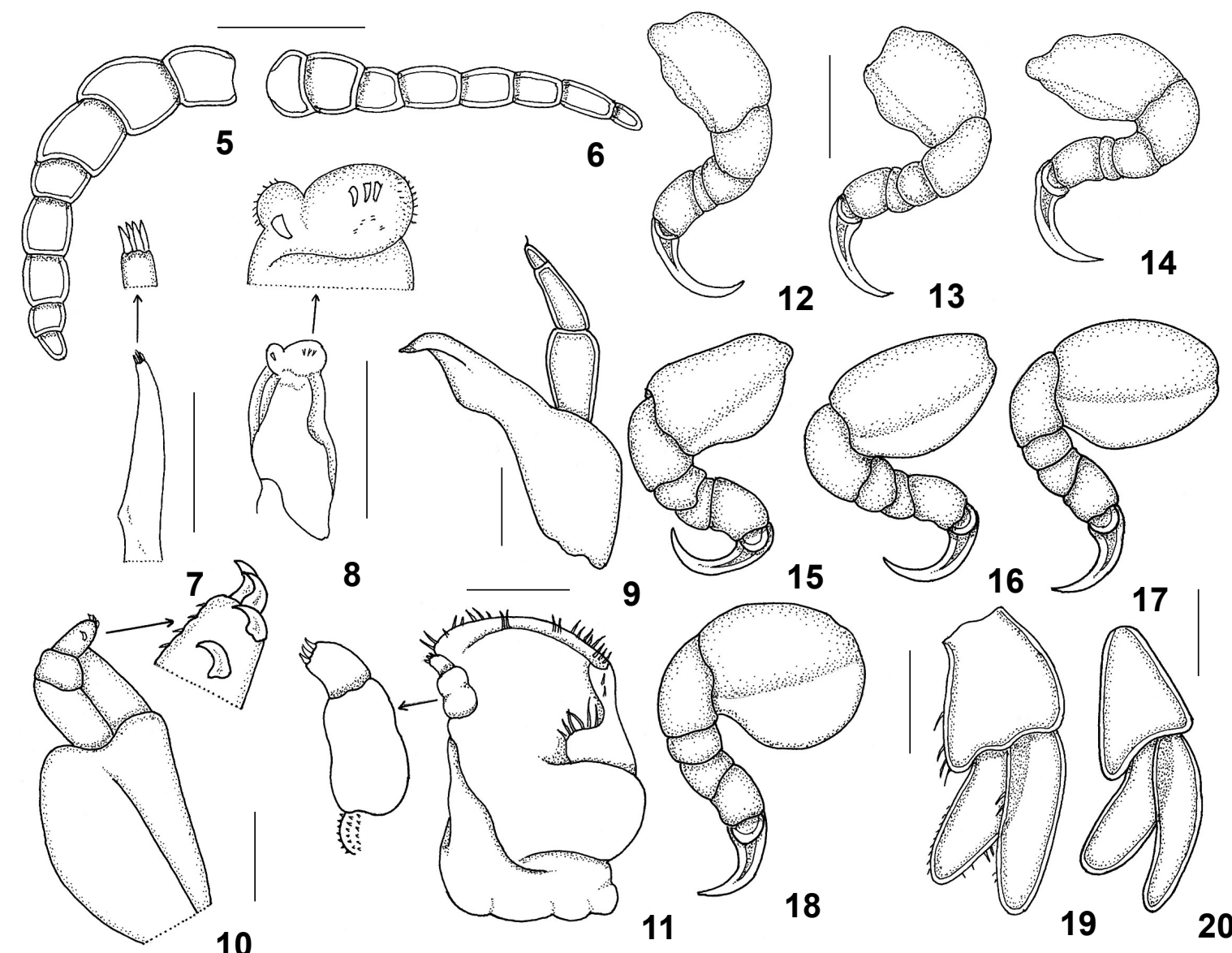

10

18

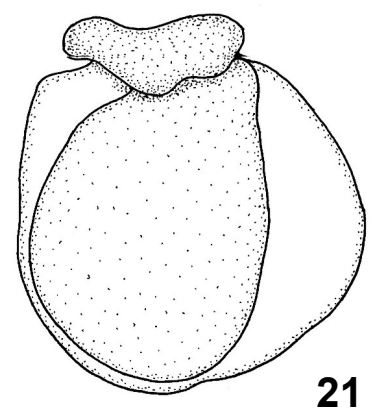

21
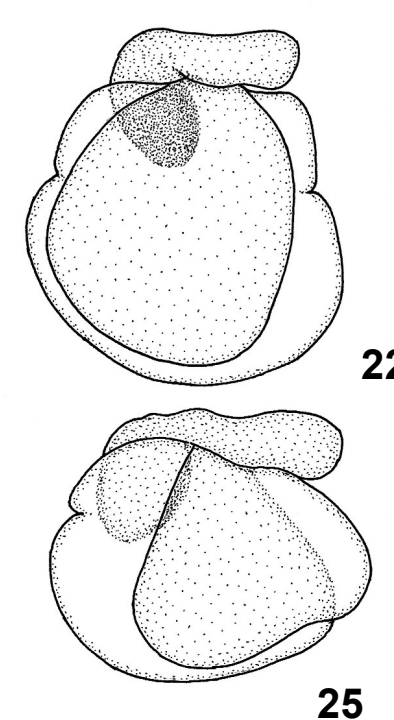
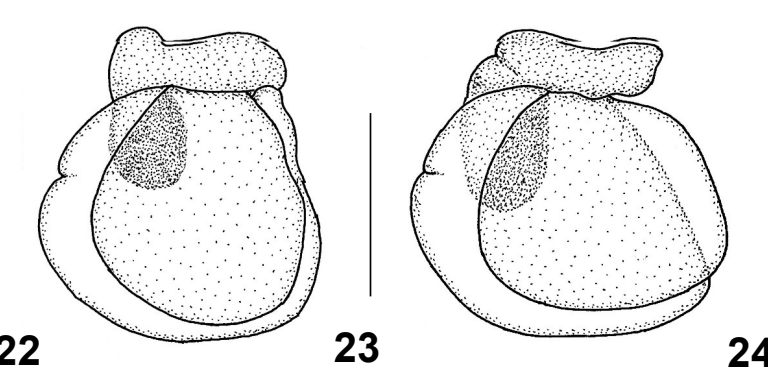

20

Figures 5-26. (5-11) Cymothoa catarinensis sp. nov.: (5-9 and 11) female, 10 male: (5) antennule; (6) antenna; (7) maxillule; (8) maxilla; (9) mandible and palp; (10) male maxilliped; (11) female maxilliped. (12-20) Pereopods and uropods: (12-18) female pereopods 1-7; (19) female uropod; (20) male uropod. (21-26) Pleopods: (21-25) female pleopods 1-5; (26) male pleopod 2. Scales: 5-8 and $11=500 \mu \mathrm{m} ; 9-10=200 \mu \mathrm{m}, 12-19=1000 \mu \mathrm{m}, 20=500 \mu \mathrm{m}, 21-26=1000 \mu \mathrm{m}$. 

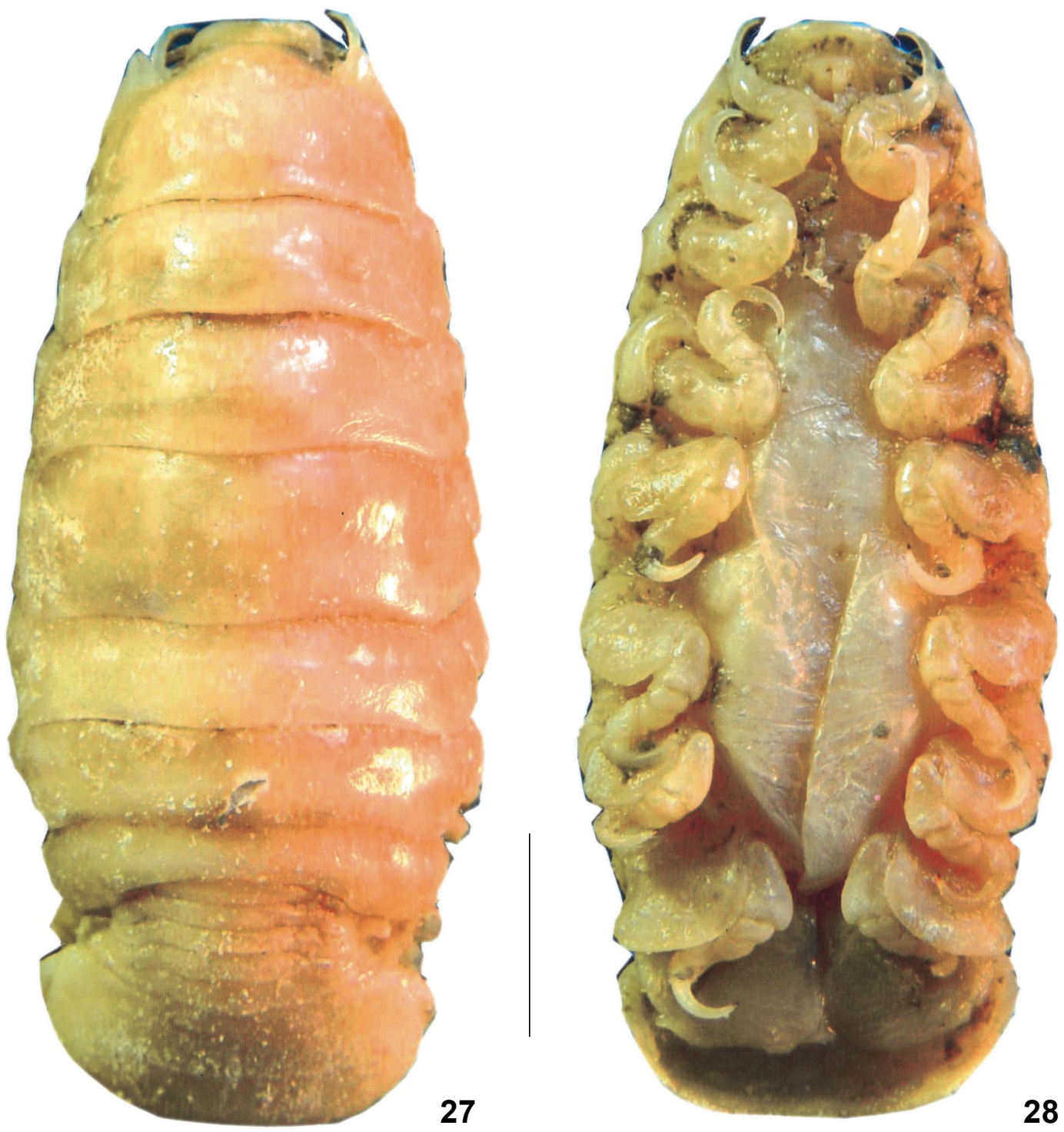

Figures 27-28. Cymothoa excisa female: (27) dorsal view; (28) ventral view. Scale $=5000 \mu \mathrm{m}$.

deeply immersed pleon, prominent and acute anterolateral angles of pereonite 1 , bilaminate pleopods with small accessory gills on the bases and a pleotelson two to three times wider than long.

\section{Cymothoa excisa Perty, 1830 Figs 27-51}

Host: Micropogonias furnieri (Demarest, 1823); Sciaenidae. Site: Mouth, over tongue.

Locality: Saco dos Limões, Baia Sul, Ilha de Florianopolis, Santa Catarina, Brazil. Colector: Glauco Fernando Jost: April to December, 2000.
Prevalence: $13 \%$.

Intensity: 1/infected fish.

Voucher specimens: Three females and one male deposited in the Crustacean Collection of the Instituto Nacional de Pesquisas da Amazônia (INPA), Manaus, Amazonas, Brazil.

Description (based on three females and one male; measurements in table II): Female (Figs 27-28): Body large, 2.3 times longer than wide; widest at level of pereonite 5 . Cephalon immersed in pereonite 1 ; frons broadly truncate; eyes present but not prominent. Antennule (Fig. 29) of 8 articles the first three being stouter; distal article with 7 small apical spines. Antenna (Fig. 30) more slender than antennule, composed of 9 articles, the first 5 being longer and wider than others. Mouth-

Revista Brasileira de Zoologia 20 (3): 541-552, setembro 2003 
Table I. Measurements ( $\mathrm{mm}$ ) of 16 females and 8 males of Cymothoa catarinensis sp. nov. Means in parentheses.

\begin{tabular}{|c|c|c|c|c|}
\hline \multirow{2}{*}{ Gender } & \multicolumn{2}{|c|}{ Body } & \multicolumn{2}{|c|}{ Pleotelson } \\
\hline & Length & Width & Length & Width \\
\hline \multirow[t]{17}{*}{ Females } & 16.5 & 9.0 & 2.0 & 7.0 \\
\hline & 16.0 & 8.0 & 3.0 & 6.0 \\
\hline & 15.2 & 7.0 & 2.0 & 5.5 \\
\hline & 150 & 8.0 & 2.5 & 6.0 \\
\hline & 140 & 6.0 & 2.0 & 5.0 \\
\hline & 14.0 & 5.5 & 3.0 & 5.0 \\
\hline & 14.0 & 6.0 & 2.5 & 4.5 \\
\hline & 14.0 & 8.0 & 2.0 & 6.0 \\
\hline & 13.0 & 6.0 & 2.0 & 5.5 \\
\hline & 12.0 & 6.0 & 2.0 & 4.5 \\
\hline & 12.5 & 6.2 & 2.0 & 5.0 \\
\hline & 11.9 & 6.8 & 1.8 & 4.4 \\
\hline & 11.5 & 5.0 & 1.8 & 4.0 \\
\hline & 11.0 & 5.0 & 1.5 & 4.0 \\
\hline & 10.2 & 6.2 & 1.8 & 4.4 \\
\hline & 9.6 & 5.8 & 1.4 & 3.4 \\
\hline & $(13.2)$ & (6.5) & $(2.1)$ & $(5.0)$ \\
\hline \multirow[t]{9}{*}{ Males } & 12.0 & 6.0 & 2.0 & 4.0 \\
\hline & 10.5 & 5.0 & 1.5 & 4.0 \\
\hline & 9.2 & 3.8 & 1.5 & 3.0 \\
\hline & 8.5 & 4.0 & 1.0 & 3.0 \\
\hline & 8.0 & 4.0 & 1.5 & 2.5 \\
\hline & 8.0 & 4.0 & 1.0 & 3.0 \\
\hline & 7.8 & 4.5 & 1.0 & 2.2 \\
\hline & 7.5 & 4.4 & 1.4 & 2.8 \\
\hline & (8.9) & (4.5) & (1.4) & (3.0) \\
\hline
\end{tabular}

Table II. Measurements ( $\mathrm{mm}$ ) of three ovigerous females and one male of Cymothoa excisa, and of 1 ovigerous female of Cymothoa oestrum.

\begin{tabular}{lccccc}
\hline \multirow{2}{*}{ Species } & \multicolumn{4}{c}{ Measurements } \\
\cline { 2 - 3 } \cline { 5 - 6 } $\begin{array}{l}\text { Cymothoa excisa } \\
\text { Females }\end{array}$ & Length & Width & & Length & Width \\
& 26.0 & 11.4 & & 3.3 & 9.0 \\
& 26.0 & 12.5 & & 3.1 & 9.2 \\
& 22.0 & 10.8 & & 3.4 & 8.6 \\
Male & 14.3 & 6.1 & & 2.5 & 5.1 \\
\hline Cymothoa oestrum & & & & \\
Female & 28.0 & 13.0 & & 4.0 & 8.4 \\
\hline
\end{tabular}

parts (Figs 31-34): Mandible with chitinous, acute incisor and rounded molar process; palp of 3 articles, shorter than mandible. Maxillule with 4 stout, recurved apical spines. Maxilla bilobed with 3 stout recurved spines on external lobe

and 7 small spines and numerous spinules on internal lobe. Maxilliped with setae on distal margin; palp of 2 articles with few spines and spinules. Pereon only moderately convex; pereonites 1 and 4 subequal in length, pereonites 2 and 3 subequal in length, 5-7 decreasing in length. Pereopods (Figs 35-41) with large claw-like dactyls; low carinae on bases of pereopods 1-3, high carinae on 4-7. Pleon immersed in pereonite 7; pleotelson 2.6 times wider than long; pleopods (Figs 42-46) trilaminate, gradually decreasing in size from 1-5. Uropods (Fig. 47) with short rami; exopod only slightly longer than endopod; not reaching posterior margin of pleotelson.

Male: similar to female but smaller. Maxilliped (Fig. 50) more slender than that of female; palp distal rather than on the internal margin as in female. Pleopods (Figs 48-49)

bilaminate; pleopod 2 without appendix masculinum. Uropod (Fig. 51) with slender rami; exopod longer than endopod.

Discussion. Distinguishing characters of Cymothoa excisa are its large size; deeply immersed, truncate cephalon; acute anterolateral angles of pereonite 1 which reach or surpass the eyes; deeply immersed pleon; trilaminate pleopods in the female with bilaminate pleopods in the male and a pleopod 2 in the male that lacks an appendix masculinum.

\section{Cymothoa oestrum (Linnaeus, 1793) Figs $52-76$}

Hosts: According to Trilles (1991), this species has been found on a number of different hosts, including: Caranx latus, C. rubber, Priacanthus arenatus, Trachurops crumenophthalmus and Tarpon atlanticus. The host of the present specimen is unknown but was probably a species of Caranx.

Site: Mouth, over tongue.

Localities: Camboriú, Santa Catarina State, Brazil. This species has been found from Key West, Florida, to Venezuela but has not been reported previously from Brazil.

Intensity: $1 /$ infected fish.

Male: Unknown.

Voucher specimen: One female deposited in the collections of the Zoology Department, UFPR, Curitiba, Paraná, Brazil.

Species description (based on single female containing 770 mancas in the marsupium): Female (Figs 52-53): Body large, 2.2 times longer than wide; widest at level of pereonites 5 and 6. Cephalon deeply immersed in pereonite 1; frons truncate; eyes absent; anterolateral margins of pereonite 1 large, rounded.

Antennule (Fig. 58) of 8 articles, the first 3 being stouter than others, terminal 3 with small spinules. Antenna (Fig. 59) composed of 9 articles, the first 3 being stouter than others. Mouthparts (Figs 60-63): Mandible with sharp incisor and rounded molar process; palp of 3 articles, longer than mandible. Maxillule with 4 terminal recurved spines. Maxilla bilobed, with 3 stout spines on external lobe and numerous spinules on outer lobe. Maxilliped with few small setae on distal margin; palp of 2 articles subequal in length but basal article 3 times wider than terminal one; palp situated medially and subapically, terminal segment with 3 stout spines. Pereon

Revista Brasileira de Zoologia 20 (3): 541-552, setembro 2003 


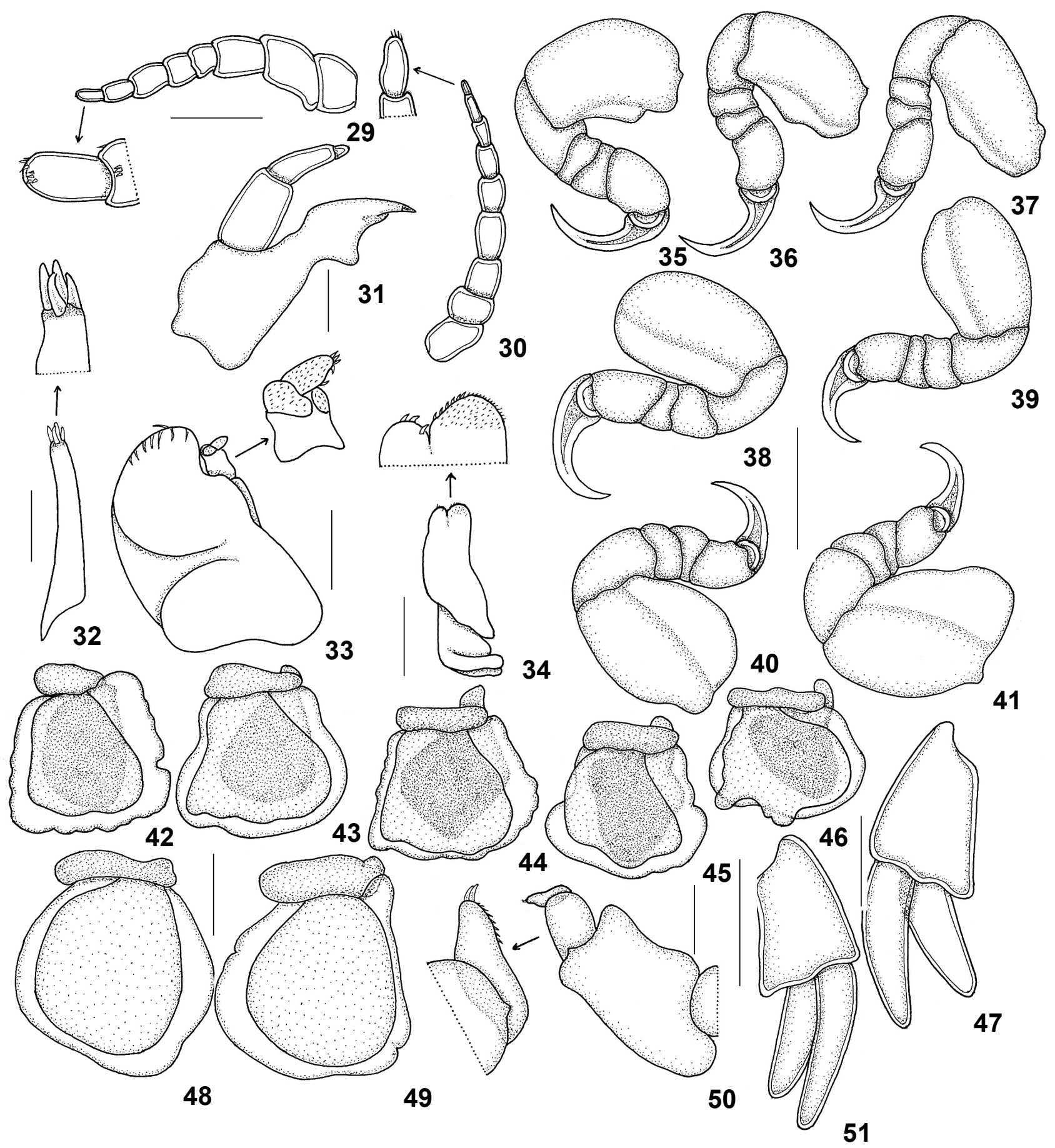

Figures 29-51. (29-47) Cymothoa excisa female: (29) antennule; (30) antenna; (31) mandible and palp; (32) maxillule; (33) maxilliped; (34) maxilla; (35-41) Cymothoa excisa female pereopods 1-7; (42-46) pleopods 1-5; (47) uropod. (48-51) male: (48-49) pleopods 1-2; (50) maxilliped; (51) uropod. Scales: 33,47 and $51=1000 \mu \mathrm{m}, 29-32,34$ and $50=500 \mu \mathrm{m}, 35-41=2000 \mu \mathrm{m}, 42-46=1000 \mu \mathrm{m}, 48$ $49=1 \mathrm{~mm}$. 

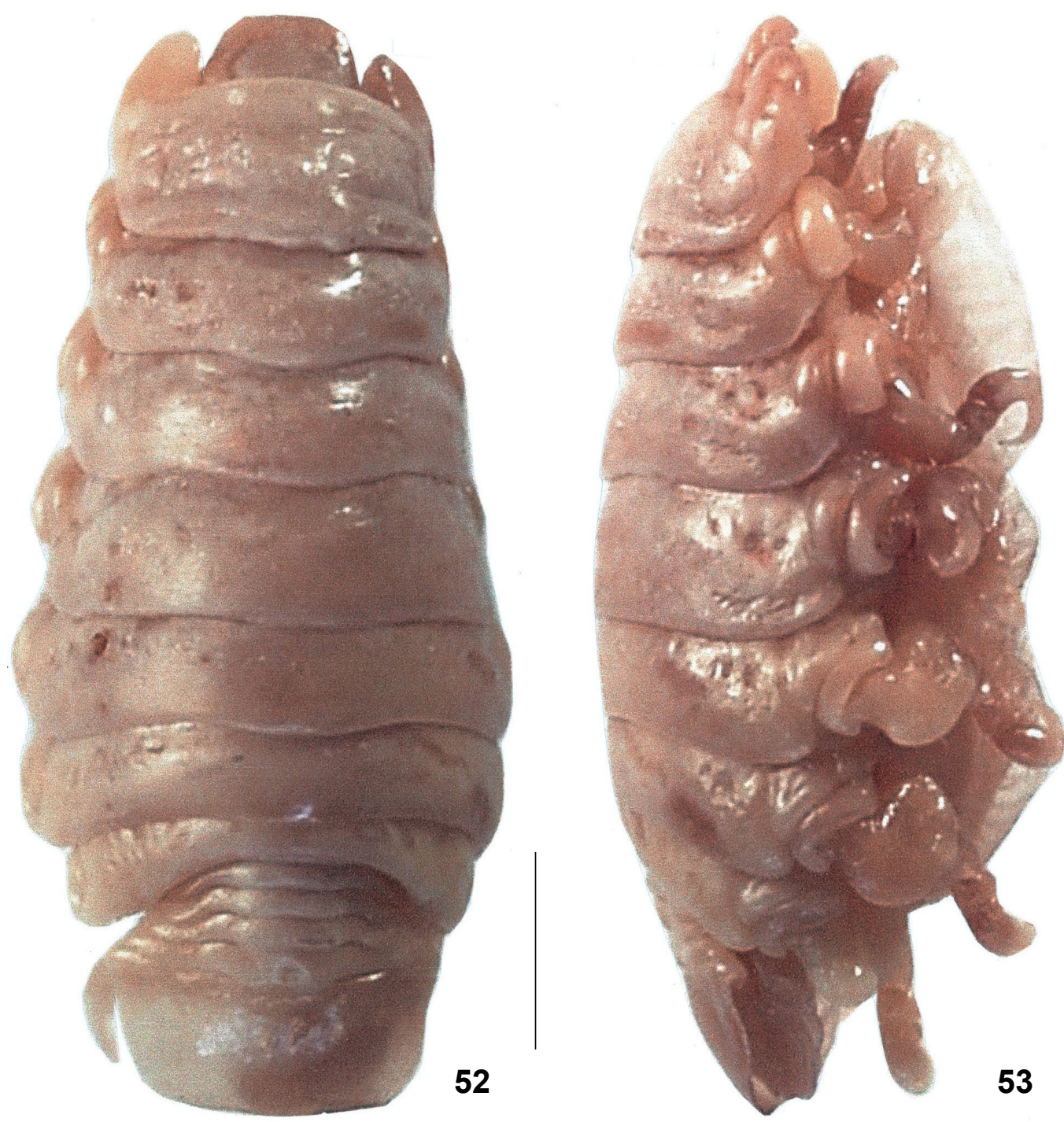

Figures 52-53. Cymothoa oestrum female: (52) dorsal view; (53) lateral view. Scale $=5000 \mu \mathrm{m}$.

moderately convex; pereonite 1 longest and 7 shortest. Pereopods (Figs 64-70) 4-7 manifestly larger than 1-3; basal carinae increasing in size from 5-7. Pleon little immersed in pereonite 7; pleotelson 2.8 times wider than long; pleopods (Figs 71-75) bilaminate, with small basal accessory gills; 5 with folds on endopod. Uropod (Fig. 76) with rami subequal in size and few spinules on basis.

Male: unknown.

Manca (Figs 54 and 56): Body about $2800 \mu \mathrm{m}$ long and $1000 \mu \mathrm{m}$ wide. Cephalon $350 \mu \mathrm{m}$ long and $550 \mu \mathrm{m}$ wide; eyes small, ovoid, red. Antennule of 8 articles, reaches to pereonite 2; antenna of 12 articles, reaches pereonite 6. Uropods long, bases extend to or beyond posterior margin of pleotelson; rami subequal in length. The manca of this species was figured, but not described, in RICHARDSON (1905).
Discussion. Distinguishing characters of Cymothoa oestrum are its large size; deeply immersed truncate cephalon, without eyes; anterolateral margins of pereonite 1 blunt and bilaminate pleopods with folding on the fifth endopod.

Other species of Cymothoa reported from Brazil

\section{Cymothoa liannae Sartor \& Pires, 1988 Fig. 77}

Host: Chloroscombrus chrysurus.

Site: Mouth, over tongue.

Geographic distribution: Rio de Janeiro to Rio Grande do Sul States, Brazil.

Species description (adapted from Sartor \& Pires 1988): Female: Body elongate, sides nearly parallel, expanding slightly 


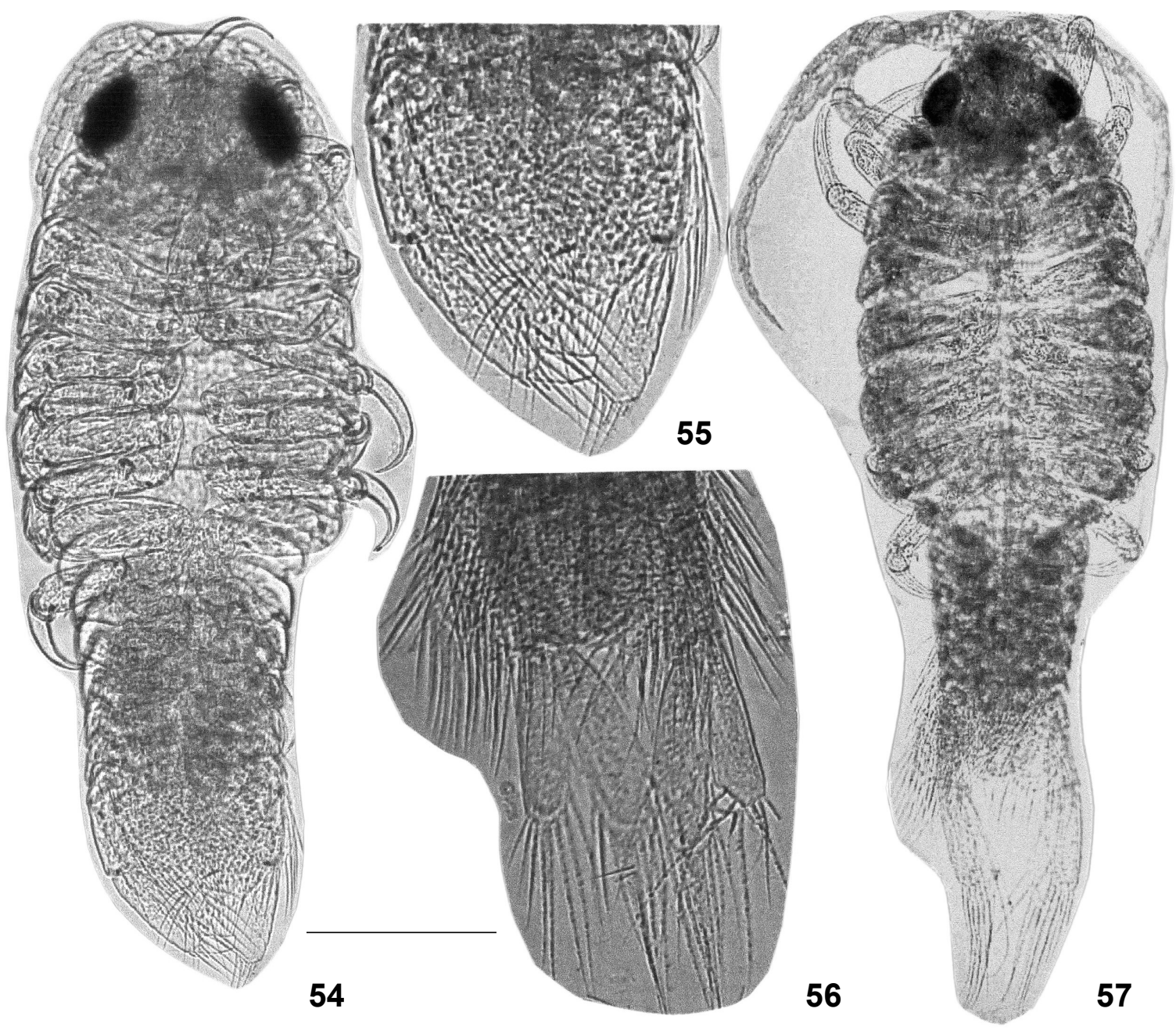

Figures 54-57. Mancas. (54-55) Cymothoa catarinensis sp. nov.: (54) dorsal view; (55) pleotelson and uropods. (56-57) Cymothoa oestrum: (56) pleotelson and uropods; (57) dorsal view. Scales: 54 and $57=500 \mu \mathrm{m}, 55-56=250 \mu \mathrm{m}$.

posteriorly, with dark brown chromatophores; widest at level of pereonites 4-6. Cephalon slightly wider than long, deeply immersed in pereonite 1 ; eyes vestigial or absent. Antennules of 8 articles; antennae of 8 articles, shorter and narrower than antennules. Pereonite 1 longest, 2-5 subequal in length, 6 shorter and 7 very short; lateral margins of pereonite 7 reaching level of pleonite 3. Pereopods 4-7 with low carinae on bases. Pleon abruptly narrower than pereon, not deeply immersed in pereonite 7; pleopod 2 with appendix masculinum. Pleotelson broadly rounded posteriorly; about as long as wide. Uropods short, reaching a little beyond middle of pleotelson. Measurements: 13-27.5 (19) $\mathrm{mm}$ long and 6-12 (8.4) $\mathrm{mm}$ wide.

Adult male: Similar to female, but smaller. Eyes small, but visible. Antennules with 8 articles; antennae with 8-9 articles. Pereonite 1 longest, 7 shortest; pereopod 7 longer than 6; large carinae on bases of all pereopods. Penis well developed; pleopod 2 with appendix masculinum longer than endopod. Pleotelson slightly wider than long. Uropods not reaching posterior margin of pleoelson. Measurements: 5.5-14 (10) $\mathrm{mm}$ long and 2.7-6.5 (4.6) $\mathrm{mm}$ wide.

Manca: SARTOR \& PIRES (1988) described the manca of their new species in some detail. They reported the following: Body 1.95-2.50 (2.19) $\mathrm{mm}$ long and 0.7-1.0 (0.86) $\mathrm{mm}$ wide. Cephalon subtriangular, 1.2 times wider than long. Antennule of 8 articles, reaching pereonite 1 ; antenna of 12-14 articles reaching pereonite 6 . Uropods surpassing posterior margin of pleotelson. The manca of this species strongly resembles that of Cymothoa oestrum in view of its long antennae and uropods. Neither of these mancas resembles that of Cymothoa catarinensis sp. nov.

Discussion. Distinguishing characters of adult females of $C$. liannae are: a deeply immersed cephalon with vestigial eyes; a pereon with nearly parallel sides; a pleonite 1 with low, blunt anterolateral angles; a pleon that is little immersed and a rounded pleotelson. 


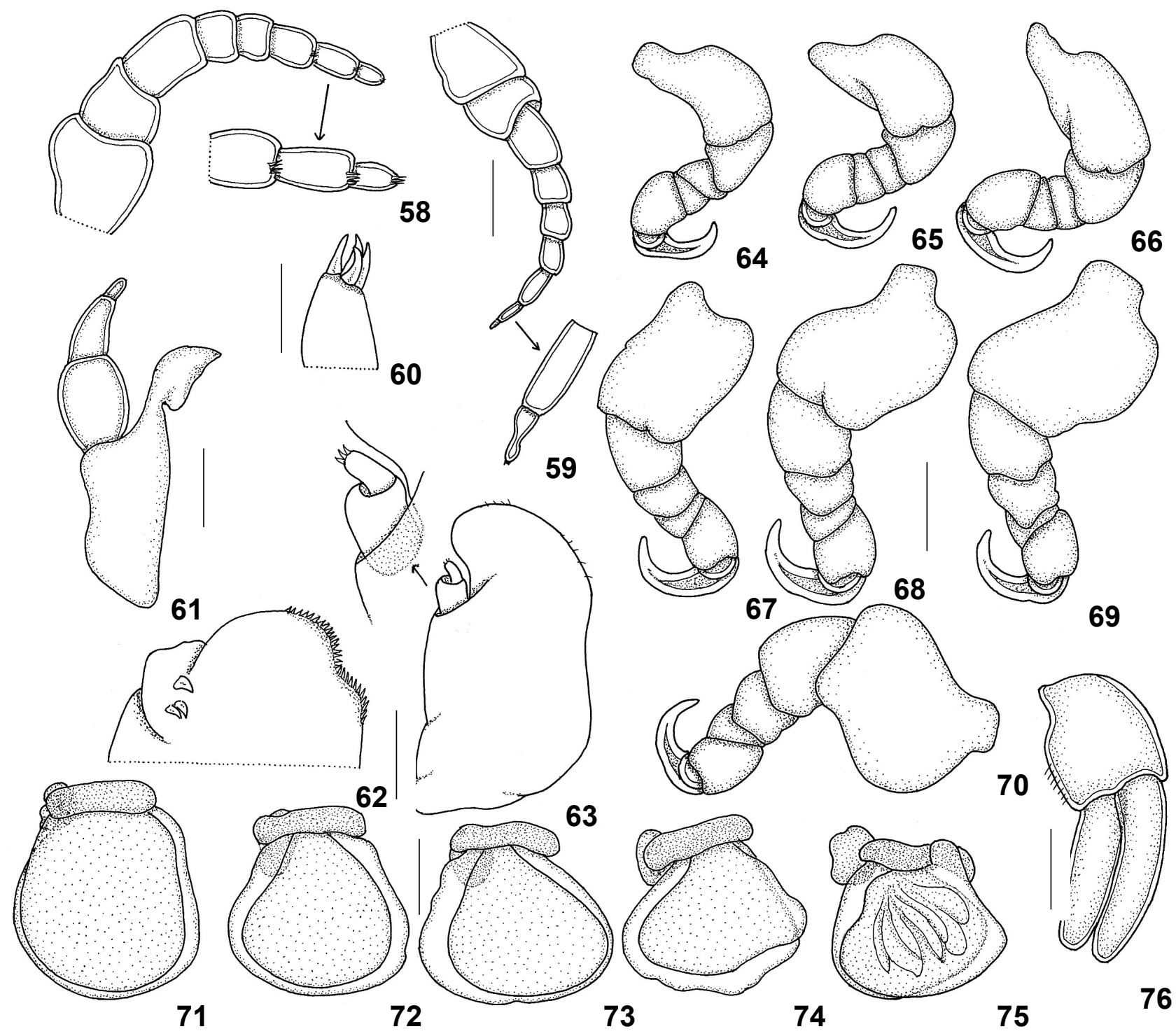

Figures 58-76. Cymothoa oestrum female: (58) antennule; (59) antenna; (60) maxillule; (61) mandible and palp; (62) maxilla; (63) maxilliped; (64-70) pereopods 1-7; (71-75) pleopods 1-5; (76) uropod. Scales: 58, 59 and $60=500 \mu \mathrm{m}, 61-62=200 \mu \mathrm{m}, 63$ and $76=$ $1000 \mu \mathrm{m}, 64-75=2000 \mu \mathrm{m}$.

\section{Cymothoa brasiliensis Schiödte \& Meinert, 1884}

\section{Fig. 79}

Hosts: Sargus sp., Caranx sp.

Site: Mouth, over tongue.

Geographic distribution: Western Atlantic Ocean from Trinidad to Rio de Janeiro, Brazil.

Species description: No detailed description of this species is available and apparently the type material has been lost. Ac- cording to TriLles $(1979,1981)$ this species is rare, at least in collections. He was able to examine 5 specimens, he identified as $C$. brasiliensis, in Holland. They ranged in length from 11 to $21 \mathrm{~mm}$. Distinguishing characters. According to the figure of $C y$ mothoa brasiliensis in SCHIÖDTE \& MEINERT (1884), redrawn here as figure 79 , the adult female has a free cephalon with prominent eyes, low and blunt anterolateral angles on pereonite 1 , a deeply immersed pleon and lateral margins of pereonite 7 that reach or even overlap the pleotelson. 

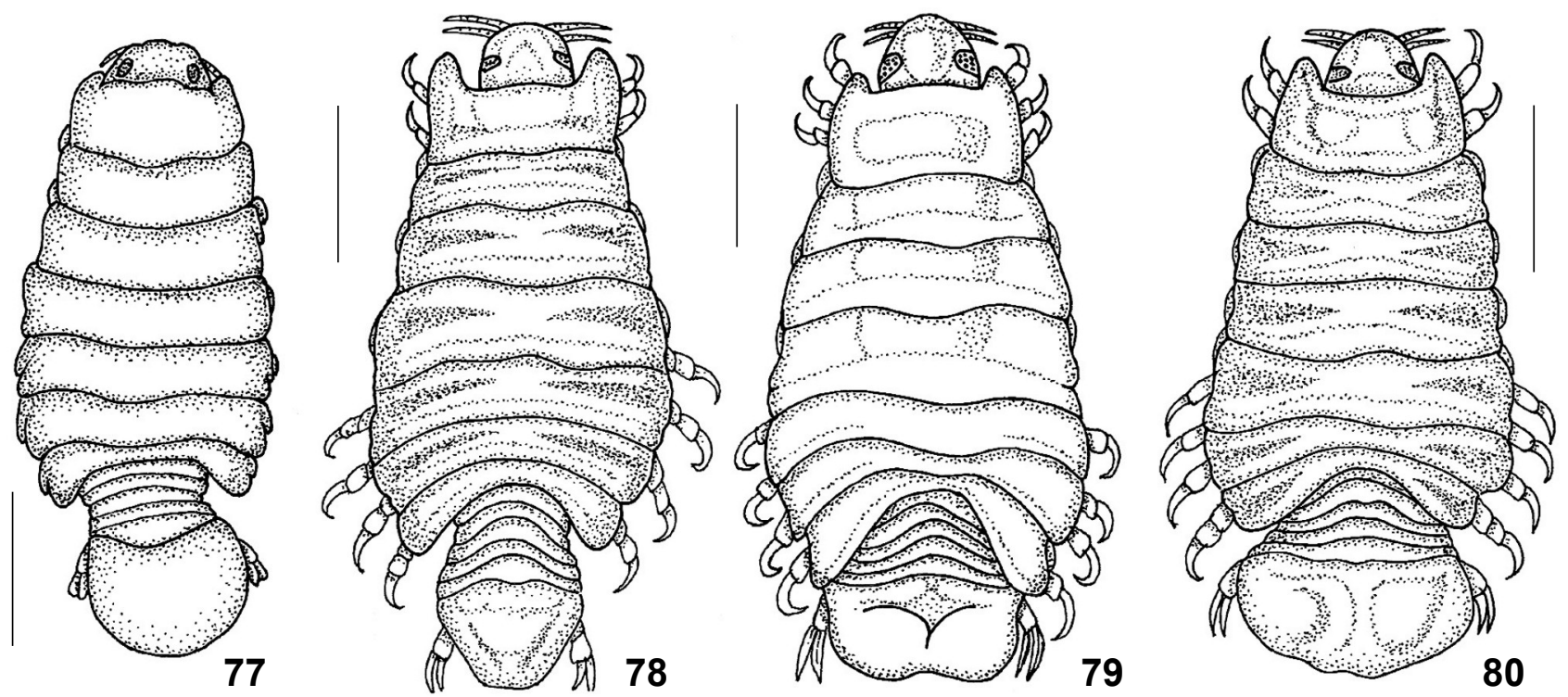

Figures 77-80. Females of other species of Cymothoa: (77) C. liannae; (78) C. geris; (79) C. brasiliensis; (80) C. ianuarii. Scales: $78=3000$ $\mu \mathrm{m}$, all other scales $=5000 \mu \mathrm{m}$.

\section{Cymothoa gerris Schiödte \& Meinert, 1884 Fig. 78}

Host: Gerres brasiliani (Cuvier, 1824).

Site: Mouth, over tongue.

Geographic distribution: The description of this species was based on a single female specimen collected along the coast of Northeastern Brazil in the 1880's and it has not been reported since.

Species description (adapted from Schiödte \& Meinert 1884): Ovigerous female: Body about twice as long as wide; widest at level of pereonites 4 and 5. Cephalon slightly wider than long, not immersed in pereonite 1, frons rounded, eyes present. Anterolateral angles of pereonite 1 large, blunt, surpassing eyes. Antennules of 8 articles; antennae of 9 articles. Pereopods 1-3 smaller, 4-7 of increasing length; low carinae on bases of 4-7; dactyls long, stout, curved. Pleon abruptly narrower than pereon, not immersed in pereonite 7. Pleotelson triangular; uropods reaching posterior margin of pleotelson. Measurement: $13 \mathrm{~mm}$ long.

Distinguishing characters. According to the figure of Cymothoa gerris in SCHIÖDTE \& MEINERT (1884), redrawn here as figure 78 , the adult female has a free cephalon with visible eyes; high, blunt anterolaterl angles on pereonite 1 that surpass the eyes anteriorly; a pleon that is not immersed in pereonite 7; a triangular pleotelson and uropods that reach the posterior margin of the pleotelson.

\section{Cymothoa ianuarii Schiödte \& Meinert, 1884 Fig. 80}

Hosts: Priacanthus sp., Platessa sp.

Site: Mouth, over tongue.

Geographic distribution: Two females of this species were collected near Rio de Janeiro, Brazil, in the 1880's.

The species has not been found since and apparently the type material has been lost.

Species description (adapted from Schiödte \& MeInerT 1884): Female without eggs: Body twice as long as wide; widest at level of pereonite 5. Cephalon wider than long, immersed in pereonite 1 , frons rounded, eyes visible. Anterolateral angles of pereonite 1 surpassing eyes. Antenules of 8 articles; antennae of 9 articles. Pereopods 1-3 manifestly smaller than 4-7 which gradually increase in length; 4-7 with carinae on bases. Pleon immersed in pereonite 7 , increasing in width posteriorly. Pleotelson twice as wide as long. Uropods not reaching posterior margin of pleotelson. Measurements: 13.5-20 mm long.

Distinguishing characters. According to the figure of Cymothoa ianuarii in SCHIÖDTE \& MEINERT (1884), redrawn here as figure 80 , the female has a cephalon immersed in pereonite 1 and prominent eyes; anterolateral angles of pereonite 1 that surpass the eyes; a tapered pleon that is immersed in pleonite 7 and a pleotelson that is twice as wide as long.

A key is presented herein as an aid to the separation of the species of Cymothoa known from Brazilian waters.

\section{Key to adult females of Brazilian Cymothoa}

1. Eyes absent. Pereopods 4-7 manifestly larger than 1-3 (Figs 52-53) C. oestrum

2. Eyes present. Pereopods 1-7 subequal in size

3. Pleon not immersed in pereonite 7 :

A. Pleotelson triangular (Fig. 78) . C. gerris

B. Pleotelson rounded, shield-like (Fig. 77) ....... C. liannae

4. Pleon immersed in pereonite 7 to a greater or lesser degree. A. Pleon deeply immersed in pereonite 7 :

(1) Cephalon not immersed in pereonite 1. Pleotelson

Revista Brasileira de Zoologia 20 (3): 541-552, setembro 2003 
about 2 times wider than long (Fig. 79) .....

C. brasiliensis

(2) Cephalon immersed in pereonite 1. Pleotelson about 3 times wider than long (Figs 1-2).... C. catarinensis sp. nov.

B. Pleon less deeply immersed in pereonite 7 :

(1) Cephalon not deeply immersed in pereonite 1 . Pereonites 5-6 much wider than 4 (Fig. 80) C. ianuarii

(2) Cephalon deeply immersed in pereonite 1 . Pereonites 4-6 subequal in width (Figs 27-28) . C. excisa

\section{ACKNOWLEDGEMENTS}

The authors thank the following institutions and individuals for their collaboration: Financial aid was provided by the Departamento de Estradas de Rodagem, Santa Catarina State (DER-SC) through the project on environmental monitoring along the express highway SC-Sul, Baia Sul, Florianopolis. Logistical support was provided by CTTMar/UNIVALI, the Third Platoon of Environmental Police of Santa Catarina - Aquatic Platoon, Florianopolis and by the Santa Catarina Yacht Club. Prof. Ricardo Corbetta and the fisherman Maciel Antônio aided in collecting fish hosts

\section{REFERENCES}

Richardson, H. 1905. Isopods of North America. Bulletin \# 54 of the United States National Museum, 727p.

SARTOR, S.M. 1986. Incidência de isópodos parasitas (Cymothoidae) em peixes da plataforma continental brasileira. Boletim do Instituto de Oceanografia, São Paulo, 34: 1-12.

SARTOR, S.M. \& A.M.S. Pires. 1988. The occurrence of Cymothoa liannae, a new species of cymothoid isopod from Brazil, with a comparative study of its post-marsupial development. Crustaceana, Bilthoven, 55: 147-156.

SCHIÖDTE, J.C. \& F. MeInERT. 1884. Symbolae ad monografiam Cymothoarium Crustaceorum Isopodium Familiae. IV. Cymothoidae. Trib. III. Livonecinae. Naturhist. Tidsskr., Ser. III, Leiden, 14: 221-454.

Thatcher, V.E. 2000. The isopod parasites of South American fishes, p. 193-226. In: G. SALGAdo-Maldonado; A.N. GarciaAldrete \& V.M. Vidal-Martinez. Metazoan Parasites in the Neotropics. México, D.F, Universidad Nacional Autónoma de México Press, 310p.

Trilles, J.P. 1979. Les Cymothoidae (Isopods, Flabellifera; parasites de poissons) du Rijksmuseum Van Natuurlijke Historie de Leiden. II. Afrique, Amérique et Régions Indoouest-Pacifiques. Zool. Meded., Leiden, 54: 245-275.

Trilles, J.P. 1981. Les Cymothoidae (Isopoda, Flabelllifera; parasites de poissons) des Antilles. Bull. Mus. Natn. Hist. Nat., Paris, (2): 583-602.

- 1991. Catalogue mondial des Cymothoidae. Studia Marina. Kotor, 21/22 (1-2): 5-288.

Received in 31.III.2003; accepted in 28.VIII.2003.

Revista Brasileira de Zoologia 20 (3): 541-552, setembro 2003 